\title{
Influence of carbonized crop residue on soil carbon storage in red pepper field
}

\author{
Jae-Ho Lee', Ji-Young Eom², Seok-hee Jeong ${ }^{2}$, Seung-Bum Hong ${ }^{1}$, Eun-Jin Park ${ }^{1}$ and Jae-Seok Lee ${ }^{2^{*}}$ (D)
}

\begin{abstract}
Background: Because of climate change, interest in the development of carbon pools has increased. In agricultural ecosystems, which can be more intensively managed than forests, measures to control carbon dioxide $\left(\mathrm{CO}_{2}\right)$ emission and absorption levels can be applied relatively easily. However, crop residues may be released into the atmosphere by decomposition or combustion. If we can develop scientific management techniques that enable these residues to be stocked on farmland, then it would be possible to convert farmlands from carbon emission sources to carbon pools. We analyzed and investigated soil respiration (Rs) rate characteristics according to input of carbonized residue of red peppers (Capsicum annuum L.), a widely grown crop in Korea, as a technique for increasing farmland carbon stock.

Results: Rs rate in the carbonized biomass (CB) section was $226.7 \mathrm{mg} \mathrm{CO}_{2} \mathrm{~m}^{-2} \mathrm{~h}^{-1}$, which was $18.1 \%$ lower than the $276.9 \mathrm{mg} \mathrm{CO} \mathrm{m}^{-2} \mathrm{~h}^{-1}$ from the red pepper residue biomass (RB) section. The Rs rate of the control was $184.1 \mathrm{mg} \mathrm{CO}_{2}$ $\mathrm{m}^{-2} \mathrm{~h}^{-1}$. In the following year, Rs in the $\mathrm{CB}$ section was $204.0 \mathrm{mg} \mathrm{CO}_{2} \mathrm{~m}^{-2} \mathrm{~h}^{-1}$, which was 38.2\% lower than the 330 . $1 \mathrm{mg} \mathrm{CO}_{2} \mathrm{~m}^{-2} \mathrm{~h}^{-1}$ from the RB section; the control emitted $198.6 \mathrm{mg} \mathrm{CO}_{2} \mathrm{~m}^{-2} \mathrm{~h}^{-1}$. Correlation between Rs and soil temperature ((Ts) at a depth of $5 \mathrm{~cm}$ ) was $R^{2}=0.51$ in the RB section, which was higher than the other experimental sections. A comparison of annual decomposition rates between RB and CB showed a large difference, 41.4 and 9.7\%, respectively. The results showed that carbonization of red pepper residues reduced the rates of decomposition and Rs.

Conclusions: The present study confirmed that the Rs rate can be reduced by carbonization of residue biomass and putting it in the soil and that the Rs rate and Ts $(5 \mathrm{~cm})$ were positively correlated. Based on the results, it was determined that approximately $1.2 \mathrm{tC} \mathrm{ha}^{-1}$ were sequestered in the soil in the first year and $3.0 \mathrm{t} \mathrm{C} \mathrm{ha}^{-1}$ were stored the following year. Therefore, approximately $1.5 \mathrm{tC} \mathrm{ha}^{-1}$ year $^{-1}$ are expected to be stocked in the soil, making it possible to develop farmlands into carbon pools.
\end{abstract}

Keywords: Soil respiration, Carbon sequestration, Carbon storage, Carbon source, Carbon pool, Red pepper, Crop residue, Carbonized biomass, Carbonization

\section{Background}

Carbon dioxide $\left(\mathrm{CO}_{2}\right)$, a major contributor to global climate change, is circulated in the atmosphere, vegetation, and soil through the carbon cycle, and in that process, a carbon pool is formed from accumulation at each stage (Waring and Running, 1998). In forest ecosystems, large amounts of carbon are stocked in the form of soil organic matter (SOM) and plant biomass. Accordingly, carbon stock in forest ecosystems is determined by the differences among $\mathrm{CO}_{2}$ absorption by photosynthesis and $\mathrm{CO}_{2}$ release by soil respiration (Rs),

\footnotetext{
* Correspondence: jaeseok@konkuk.ac.kr

${ }^{2}$ Department of Biological Science, Konkuk University, Seoul 05029, Republic of Korea

Full list of author information is available at the end of the article
}

and decomposition of SOM (Lee et al., 2010, Lee et al. 2013, Yoon, et al. 2013).

In agricultural ecosystems, large amounts of organic matter are produced each year from crop residues. Unlike wild plants, crops left in the field generally have a high carbon to nitrogen ratio $(\mathrm{C}: \mathrm{N})$, causing more rapid decomposition, with most $\mathrm{CO}_{2}$ returned to the atmosphere. Thus, net carbon stock absorbed from the atmosphere is generally low in agricultural ecosystems (Post and Kwon, 2000; Yoo et al., 2012). Accordingly, the Marrakesh Accords and Marrakesh Declaration (2001) recognize net ecosystem production (NEP) of greenhouse gases from forestry for carbon credits, but farmland is not yet recognized as a carbon pool (IPCC, 2001). 
Therefore, various studies have evaluated carbon sequestration on farmlands. In Kenya, long-term application (18 years) of livestock manure on corn and bean fields increased SOM at a rate of $10-23 \mathrm{~g} \mathrm{~m}^{-2}$ year ${ }^{-1}$, and relative to the total amount introduced, $5-12 \%$ of carbon was stored in the soil (Kapkiyai et al., 1999). However, applying organic matter has side effects; although it may increase carbon content in the soil, the application of organic matter also increases greenhouse gas emissions (Duxbury, 1995; Jastrow et al., 2007; Lee, Lee et al., 2013; Lee, Yoon, et al., 2013). Another carbon sequestration method being studied involves no tillage; carbon emission from tillaging is reduced and atmospheric carbon is sequestered, thereby minimizing soil disturbance and reducing Rs (Curtin et al., 2000; Luo et al., 2010; Lee, Lee et al., 2013; Lee, Yoon, et al., 2013; Tian et al. 2016).

There have been other reports on carbon sequestration in soil that studied adding carbonized crop residue biomass to the soil. However, most of the greenhouse gas studies in the agricultural sector have focused on measuring emission levels, while quantitative studies in agricultural ecosystems are lacking (Lee, Lee et al., 2013; Lee, Yoon, et al., 2013; Lee et al., 2016). If the effects of adding carbonized biomass to the soil are accurately assessed, then it may be possible to reduce $\mathrm{CO}_{2}$ emissions in agricultural ecosystems and convert them to carbon pools. Additionally, adding carbonized residue to the soil is expected to improve soil health and contribute to atmospheric carbon fixation on farmlands. Most agricultural soil has very low amounts of carbon; increased carbon accumulation may reduce soil erosion, improve tillage suitability, and increase nutrient retention (Glover et al., 2000; Gregorich et al., 2005). Therefore, establishing an effective carbon pool for farmland soil should not only increase soil carbon, but also play an important role in future farming (Campbell et al., 2005). Agricultural ecosystems, unlike most forests, have a well-established artificial management infrastructure that offers an advantage for implementing efficient carbon management (i.e., the agricultural environment facilitates retrieval and treatment of fixed organic matter). Therefore, studies on farmland carbon sequestration, based on crop choice, provide a meaningful contribution to climate change research.

Red peppers (Capsicum annuum L.), which account for the largest farmed area among field crops in Korea, have a cultivation area of 36,120 ha and annual production yield of $85,068 \mathrm{t}$. They also had the highest annual consumption rate among seasonal vegetables (KOSTAT, 2015). In Korea, red peppers are annual herbaceous plants; after their fruits are harvested, the carbon from the pepper stems (crop residue makes up a significant portion of the biomass) is mostly returned to the atmosphere by decomposition from being discarded or burned. If methods to store the various crop residues produced in agricultural ecosystems can be established, then agricultural ecosystems may be used as carbon pools. Not only for Korea, but also on a global scale, this represents a way to secure an exceptionally vast carbon pool reservoir.

The present study investigated the effects on the agricultural carbon production or absorption from adding carbonized crop residue biomass to farmland soils. We used the results to examine the methodology for possibly converting farmlands into carbon pools.

\section{Methods \\ Study site}

The study site was located in Seodun-dong, Gwonseongu, Suwon-si, Gyeonggi-do (37 $15^{\prime} 22^{\prime \prime} \mathrm{N}, 126^{\circ} 59^{\prime}$ $\left.24.5^{\prime \prime} \mathrm{E}\right)$. The mean annual air temperature and precipitation were $12.6{ }^{\circ} \mathrm{C}$ and $1378.7 \mathrm{~mm}$, respectively, from 2006 to 2015 (Data source: Suwon weather station). As of 2015, the size of cultivation area for red peppers in Suwon accounted for $1.4 \%$ (48 ha) of all cultivated land (3496 ha) in Gyeonggi Province (KOSTAT, 2005).

For this experiment, we used sandy clay loam (Gopyeong series) soil with organic matter content of $22.0 \mathrm{~g} \mathrm{~kg}^{-1}, \mathrm{NH}_{4}-\mathrm{N}$ content of $83.1 \mathrm{mg} \mathrm{kg}^{-1}$, and $\mathrm{NO}_{3}-$ $\mathrm{N}$ content of $83.9 \mathrm{mg} \mathrm{kg}-1$. These soil properties, and other pre-experiment physicochemical properties, are shown in Table 1. Soil chemistry consisted of a $\mathrm{pH}$ of

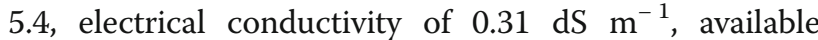
$\mathrm{P}_{2} \mathrm{O}_{5}$ of $150.1 \mathrm{mg} \mathrm{kg}^{-1}$, and exchangeable $\mathrm{K}, \mathrm{Ca}$, and $\mathrm{Mg}$ of $0.6,5.5$, and $5.2 \mathrm{cmol} \mathrm{kg}^{-1}$, respectively, and other soil properties were analyzed in accordance with the soil analysis protocol by NIAST (1988).

\section{Experimental material}

The experimental material consisted of field-grown red peppers (virus-resistant cultivar "Super Manita," Nongwoo Bio Co., Suwon, Korea). In the first year, the seeds were sown on March 8th and transplanted on May 5th; the experiment ended on October 9th. In the following year, the seeds were sown on March 12th and

Table 1 Chemical properties of the soil before the experiment

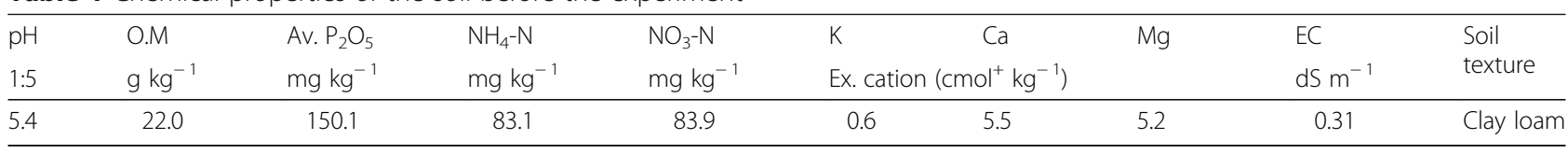


transplanted on May 3rd; the experiment ended on October 30th. Each experimental section $(2 \times 2 \mathrm{~m})$ included two furrows $(0.75 \times 2 \mathrm{~m})$. Five peppers were planted $40 \mathrm{~cm}$ apart in each furrow, for a total of 10 peppers in each experimental section. For mulch, we used black non-woven polypropylene agricultural fabric instead of black mulching vinyl.

Fertilizer was applied using the standard fertilizer application method in accordance with the Fertilizer Prescription Index provided by the Rural Development Administration (RDA, 1999). For each $2 \times 2 \mathrm{~m}$ area, we applied $87 \mathrm{~g}$ of urea, $218 \mathrm{~g}$ of fused superphosphate, and $59 \mathrm{~g}$ of potassium chloride as the base dressing 2 weeks prior to tillage and planting. We applied top dressing three times: the first top dressing (26 g urea and $30 \mathrm{~g}$ potassium chloride) was applied 40 days after planting, the second top dressing (26 g urea and $30 \mathrm{~g}$ potassium chloride) was applied approximately 30 days after the first top dressing, and the third (26 g urea) was applied approximately 30 days after the second.

\section{Experimental section design}

For pepper residue carbonization, residues were cut into $10-\mathrm{cm}$ pieces by parts (stems, leaves, roots, and fruits) and approximately $1 \mathrm{~kg}$ of residue was placed in a metal container $(30 \times 30 \times 50 \mathrm{~cm}, L \times W \times H)$; the container was completely sealed, except for the outlet for the burning gas. The sealed container was placed in a simple kiln, and the residues were carbonized for $10 \mathrm{~min}$ after the temperature inside the container exceeded $400{ }^{\circ} \mathrm{C}$.

The amount of red pepper residue biomass produced annually is $573.8 \mathrm{~g}$ per unit area. Based on a preliminary experiment on carbonized pepper residue biomass, the reference value was set to $42.1 \%$. The entire experimental section $(24 \times 13 \mathrm{~m})$ was divided into control, red pepper residue biomass $(\mathrm{RB})$, and carbonized biomass $(\mathrm{CB})$ sections (each section was $2 \times 2 \mathrm{~m}$ ). For observation of direct impact on crops based on different treatments, each treatment was applied at points close to a soil depth of $10 \mathrm{~cm}$, where the pepper roots were planted. Only soil was buried in the control section, while $573.8 \mathrm{~g} \mathrm{~m}^{-2}$ of pepper stem, based on amount of pepper residue discarded annually, was buried in the soil in the RB section. Meanwhile, $246.7 \mathrm{~g} \mathrm{~m}^{-2}$ of carbonized pepper stem was mixed thoroughly with soil and buried in the $\mathrm{CB}$ section. $\mathrm{RB}$ and $\mathrm{CB}$ residues were collected three times each month; Rs was measured prior to retrieving the residues.

\section{Measurement of soil $\mathrm{CO}_{2}$ respiration rate}

We used an automatic open/closing chamber (AOCC) system for measuring Rs (Suh et al., 2006). The AOCC, originally fabricated for forest measurement, was improved for use in an agricultural ecosystem by considering direct sunlight, high temperature, and water drainage for accurate measurement. Two AOCCs were placed in each section, and each chamber was measured for $30 \mathrm{~min}$, eight times per day.

The AOCC system was composed of three main systems: chamber, pumping, and timing. The pumping system comprised a buffer tank made from a commercial plastic vessel, an air pump (GD-6EA, Enomoto, Tokyo, Japan), a mass-flow controller (RK-1250, Kofloc, Tokyo, Japan), an air filter (TPF2000, TPC, Korea), a water trap (Perma Pure Dryer, SWG-A01-18, Asahi Glass Engineering, Chiba, Japan), and two infrared gas analyzers (IRGA) (LI-820, Li-Cor, USA). One IRGA was used to measure the $\mathrm{CO}_{2}$ concentration at the air inlet, and the other was used for the outlet. The timing system was constructed from a timer that controlled the opening and closing times of the chamber lid and relays that divided the electric power supplied by the DC motor among the chambers. The timing system also controlled opening and closing of the solenoid valves and transmission of the data from the IRGA to the terminals of a data logger (CR10X, Campbell Scientific, Logan, UT, USA). The chamber ( $3 \mathrm{~kg}$ ) could either be installed on a soil collar or attached to a cell by means of an intermediate collar. The chamber, cell, and soil collar had an elongated octagonal shape $\left(20 \times 30 \times 8 \mathrm{~cm}^{3}, L \times W \times H\right)$ to avoid any stagnation zones, and each was constructed by hand from stainless steel.

When measurement began, the pump supplied $1.8 \mathrm{~L} \mathrm{~min}^{-1}$ of buffered ambient air, collected $100 \mathrm{~cm}$ above the soil surface, from the buffer tank to the chamber. The pump also provided $0.6 \mathrm{~L} \mathrm{~min}^{-1}$ ambient air flow to the IRGA, which provided the reference $\mathrm{CO}_{2}$ value used for calculating the difference in $\mathrm{CO}_{2}$ concentrations between the inlet and outlet. In the AOCC measurements, we calculated Rs as the difference in $\mathrm{CO}_{2}$ concentration between the chamber's air inlet and outlet. A detailed description of this chamber system can be found in Suh et al. (2006). The Rs was defined as

$$
\mathrm{Rs}=(a \times V \times \rho) / A
$$

where $a\left(\Delta \mathrm{CO}_{2} / \Delta t\right)$ is the increasing rate of the $\mathrm{CO}_{2}$ concentration in the closed path system, $V$ is the volume of the closed path system, $\rho$ is the density of $\mathrm{CO}_{2}$, and $A$ is the soil surface area of the chamber. The constants in the equation convert the units to $\mathrm{mg} \mathrm{CO}_{2} \mathrm{~m}^{-2} \mathrm{~h}^{-1}$.

\section{Measurement of environmental factors}

We measured air temperature at a height of $30 \mathrm{~cm}$ and soil temperature at a depth of $5 \mathrm{~cm}$ using copperconstantan thermocouples (T-CC, $0.32 \mathrm{~mm}$, Ninomiya) at 2-min intervals for Rs measurements. Temperature measurements were taken every $20 \mathrm{~s}$, with the 5-min 
average recorded and stored with a data logger during the experimental period. The precipitation data were obtained from the Suwon weather station. Soil moisture content was measured by time domain reflectometry (TDR) (CS616, Campbell Scientific, Logan, Utah, USA). Two 30-cm-long rod-balanced probes were placed horizontally at a soil depth of $10 \mathrm{~cm}$ below the soil surface.

\section{$Q_{10}$ value}

Sensitivity of Rs to soil temperature change $\left(Q_{10}\right)$ (Fang and Moncrieff, 2001) was calculated by applying $\beta_{1}$ to Eq. 3 , after calculating $\beta_{1}$ by applying Rs rate $(y)$ and soil temperature (Ts) to the index equation (Eq. 2) (Boone et al., 1998).

$$
y=\beta_{0} \mathrm{e}^{\beta_{1} \text { Ts }}
$$

$y$ is the Rs rate $\left(\mathrm{mg} \mathrm{CO}_{2} \mathrm{~m}^{-2} \mathrm{~h}^{-1}\right), x$ is the soil temperature $\left({ }^{\circ} \mathrm{C}\right)$, and $\beta_{0}$ and $\beta_{1}$ are constants.

$$
Q_{10}=\mathrm{e}^{10 \beta_{1}}
$$

\section{Decomposition rate}

Nylon bags $(18 \times 25 \mathrm{~cm}, 1$-mm mesh size $)$ were fabricated for measuring decomposition rates of $\mathrm{RB}$ and $\mathrm{CB}$ over time. After putting $25 \mathrm{~g}$ each of $\mathrm{RB}$ and $\mathrm{CB}$ into separate nylon bags, the bags were weighed. In May of the first year, a 24-month supply of nylon bags containing $\mathrm{RB}$ and $\mathrm{CB}$, three for each month's collection (72 bags per section), were buried in soil. From June of the first year to May of the following year, three of the buried bags were retrieved monthly per section. The bags were dried for $48 \mathrm{~h}$ in an $80{ }^{\circ} \mathrm{C}$ dry oven and weighed. Decrease in weight versus the initial weight was converted to a percentage for the decomposition rate.

\section{Results and discussion}

Soil respiration rate

Rs was measured starting in September of the first year. The highest rate of Rs was found in September when the measurements began, with the $\mathrm{CB}, \mathrm{RB}$, and control sections showing 298.4, 398.2, and $233.8 \mathrm{mg} \mathrm{CO}_{2} \mathrm{~m}^{-2} \mathrm{~h}$ ${ }^{-1}$, respectively. Starting in October, as soil temperature (Ts) began to drop, the Rs rate decreased as well. At that time, the $\mathrm{CB}, \mathrm{RB}$, and control sections showed Rs rates of $222.5,268.0$, and $168.1 \mathrm{mg} \mathrm{CO} \mathrm{Cm}^{-2} \mathrm{~h}^{-1}$, respectively (Fig. 1). Analysis of the Rs rate by year showed that, in the first year, the RB section had the highest mean Rs rate with $276.9 \mathrm{mg} \mathrm{CO} \mathrm{m}^{-2} \mathrm{~h}^{-1}$, while the $\mathrm{CB}$ section emitted $226.7 \mathrm{mg} \mathrm{CO}_{2} \mathrm{~m}^{-2} \mathrm{~h}^{-1}$, which was $18.1 \%$ lower than the RB section; the control section emitted $184.1 \mathrm{mg} \mathrm{CO} \mathrm{m}^{-2} \mathrm{~h}^{-1}$, which was $33.5 \%$ lower than the $\mathrm{RB}$ section. In the following year, the RB section had the highest Rs rate $\left(330.1 \mathrm{mg} \mathrm{CO} \mathrm{m}^{-2} \mathrm{~h}^{-1}\right)$, followed, in order, by $\mathrm{CB}\left(204.0 \mathrm{mg} \mathrm{CO}_{2} \mathrm{~m}^{-2} \mathrm{~h}^{-1}\right)$ and control $\left(198.6 \mathrm{mg} \mathrm{CO}_{2} \mathrm{~m}^{-2} \mathrm{~h}^{-1}\right)$.

The comparison of Rs rates between the experimental sections showed that the $\mathrm{CB}$ section had lower values than the RB section. Thus, burying carbonized residue biomass in the soil reduced $\mathrm{CO}_{2}$ emission into the atmosphere, and the residue biomass organic matter remained sequestered in the soil instead of being returned to the atmosphere from decomposition. In the first year, the CB section showed soil Rs that was $18.1 \%$

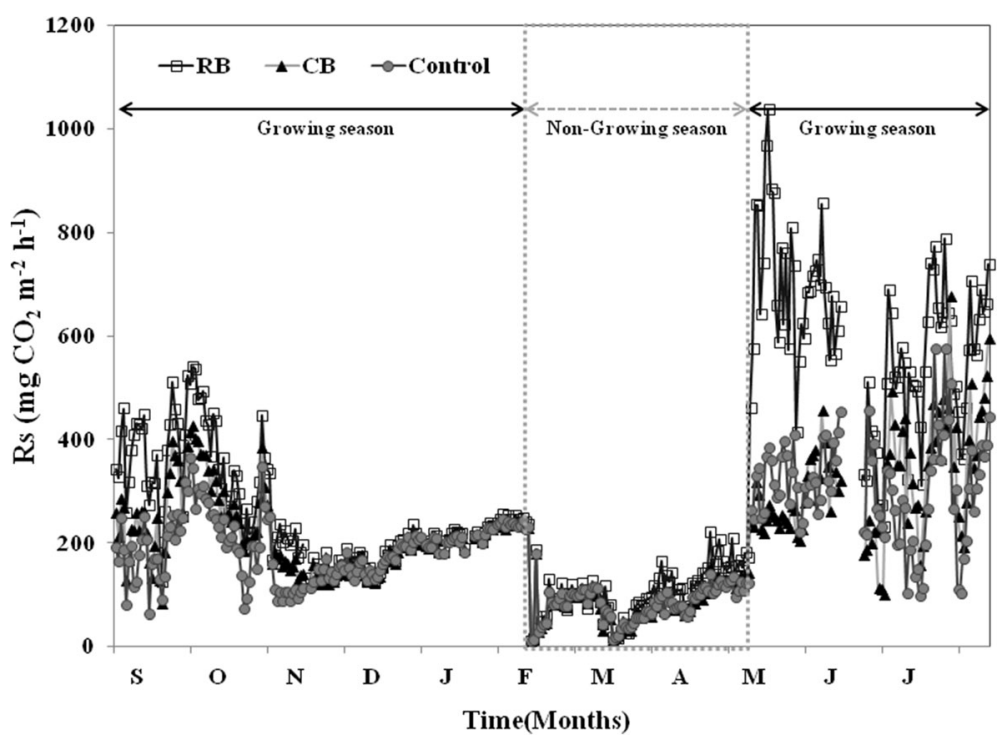

Fig. 1 Soil respiration rate (Rs) during the study period at the experimental site in Suwon. (RB, red pepper residue biomass section; CB, carbonized biomass section) 
lower than the RB section, while in the following year, the difference was $38.2 \%$. Generally, the Rs rate varied seasonally; Rs began to increase in the spring when temperature began to increase, reached its peak value during summer, and decreased thereafter. Such variation has been reported to be attributable to changes in Ts (Koizumi et al., 1999; Buchmann, 2000; Suh et al., 2006; Wang et al., 2013).

The present study also compared mean Rs rates in the experimental sections during growth (May to October) and non-growth (November to April) periods for red peppers. In the control group, Rs rates during growth and non-growth periods was $251.7 \pm 57.3$ and $133.4 \pm$ $54.1 \mathrm{mg} \mathrm{CO} \mathrm{Cm}^{-2} \mathrm{~h}^{-1}$, respectively, showing a $47.0 \%$ lower Rs rate during non-growth than during growth. In the $\mathrm{RB}$ section, there was a $67.1 \%$ difference in the Rs rate between growth $\left(463.5 \pm 146.6 \mathrm{mg} \mathrm{CO}_{2} \mathrm{~m}^{-2} \mathrm{~h}^{-1}\right)$ and non-growth $\left(152.3 \pm 51.5 \mathrm{mg} \mathrm{CO}_{2} \mathrm{~m}^{-2} \mathrm{~h}^{-1}\right)$ periods. In the $\mathrm{CB}$ section, the Rs rate during non-growth (133.5 $\pm 54.4 \mathrm{mg} \mathrm{CO} \mathrm{m}^{-2} \mathrm{~h}^{-1}$ ) was $54.5 \%$ lower than during growth $\left(293.4 \pm 45.5 \mathrm{mg} \mathrm{CO}_{2} \mathrm{~m}^{-2} \mathrm{~h}^{-1}\right)$. In the control section, the Rs rate was highest in May $(322.7 \pm 52.2 \mathrm{mg}$ $\mathrm{CO}_{2} \mathrm{~m}^{-2} \mathrm{~h}^{-1}$ ), after the peppers were planted. Rs rates began to gradually decrease starting from October $\left(168.1 \pm 66.8 \mathrm{mg} \quad \mathrm{CO}_{2} \quad \mathrm{~m}^{-2} \mathrm{~h}^{-1}\right)$; they temporarily increased in December $\left(185.5 \pm 23.8 \mathrm{mg} \mathrm{CO}_{2} \mathrm{~m}^{-2} \mathrm{~h}^{-1}\right)$ and gradually decreased again in February $(84.7 \pm$ $34.9 \mathrm{mg} \mathrm{CO} \mathrm{Cm}^{-2} \mathrm{~h}^{-1}$ ). In the $\mathrm{RB}$ section, the Rs rate was $716.1 \pm 130.5 \mathrm{mg} \mathrm{CO} \mathrm{m}^{-2} \mathrm{~h}^{-1}$ in May, showing a rapid increase after the peppers were planted. Rs rates began to gradually decrease starting in September $\left(398.2 \pm 101.8 \mathrm{mg} \mathrm{CO}_{2} \mathrm{~m}^{-2} \mathrm{~h}^{-1}\right)$; they temporarily increased in December $\left(190.5 \pm 27.5 \mathrm{mg} \mathrm{CO}_{2} \mathrm{~m}^{-2} \mathrm{~h}^{-1}\right)$ and gradually decreased again in February (89.1 \pm $35.8 \mathrm{mg} \mathrm{CO} \mathrm{Cm}^{-2} \mathrm{~h}^{-1}$ ). In the $\mathrm{CB}$ section, the Rs rate was highest in July $\left(378.5 \pm 120.0 \mathrm{mg} \mathrm{CO}_{2} \mathrm{~m}^{-2} \mathrm{~h}^{-1}\right)$. Rs rates decreased gradually in October $(222.5 \pm 55.8 \mathrm{mg}$ $\mathrm{CO}_{2} \mathrm{~m}^{-2} \mathrm{~h}^{-1}$ ); they temporarily increased in December $\left(182.8 \pm 25.0 \mathrm{mg} \mathrm{CO}_{2} \mathrm{~m}^{-2} \mathrm{~h}^{-1}\right)$ and gradually decreased again in February $\left(82.6 \pm 34.1 \mathrm{mg} \mathrm{CO} \mathrm{CO}^{-2} \mathrm{~h}^{-1}\right)$.

Between growth and non-growth periods, there were differences in Rs rates (from 47 to $67 \%$ ), which was due to pepper residue biomass being removed during the non-growth period. Generally, Rs refers to $\mathrm{CO}_{2}$ emission as the sum of root respiration of plants and respiration by animals and microbes in soil (Chae et al., 2005; Pan et al., 2015); it is suspected that the differences were due to root respiration by the pepper plant. With respect to forests, Nakane et al. (1983) reported a root respiration rate of $47-51 \%$ in an 80 -year-old pine forest, and Lee et al. (2003) reported a rate of 40-50\%; Pyo et al. (2003) reported a root respiration rate of approximately $46 \%$ in a Korean pine plantation. Although these data pertain to forests, our results from farmland soils showed a similar rate.

\section{Relationship between Ts rate and environmental factors}

Air temperature (Ta) and Ts (at a depth of $5 \mathrm{~cm}$ ) were changed per season. Ta and Ts showed a similar pattern of variation, but Ts showed a smaller margin of variation than Ta. During the observational period, mean Ta and Ts were 17.0 and $14.9{ }^{\circ} \mathrm{C}$, respectively (Fig. 2a). Previous

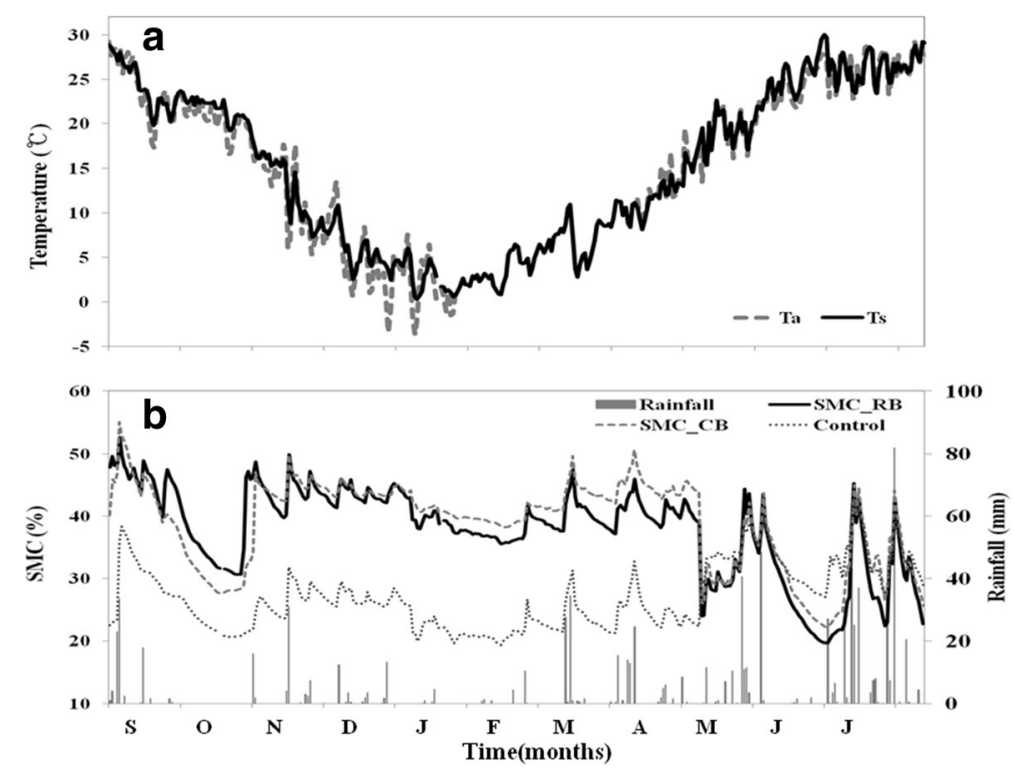

Fig. 2 Variation of soil temperature (Ts) at 5-cm depth, air temperature (Ta) (a), and soil moisture content in red pepper residue biomass section (SMC_RB), soil moisture content in carbonized biomass section (SMC_CB), soil moisture content in control section, and rainfall (b) in the first and second year at the experiment site 
studies reported that the Rs rate and Ts were positively correlated (Xu and Qi, 2001; Verma et al., 2005). To examine the correlation between the Rs rate and Ts, regression analysis was performed on Ts $(5 \mathrm{~cm})$. The results showed $R^{2}=0.35,0.52$, and 0.25 in the CB (Fig. 3), RB (Fig. 4), and control sections (Fig. 5), respectively, indicating the highest positive correlation between the Rs rate and Ts in the RB section. $Q_{10}$ value, representing the sensitivity of the Rs rate with respect to daily average change in Ts $(5 \mathrm{~cm})$ from August to July, was highest in the CB section (2.6), followed consecutively by RB (2.5) and control (1.9), with RB and $C B$ showing little difference in $Q_{10}$ values. An increase in Rs corresponds to an increase in Ts (Kucera and Kirkham, 1971; Lee, Lee, et al., 2013; Lee, Yoon, et al., 2013); however, at high temperatures, it has been reported that the response of Rs to Ts is reduced, since enzymes become inactive or denatured (Fang and Moncrieff, 2001).

With respect to soil moisture content (SMC), there was a pattern of increase that corresponded to rainfall. The CB section had the highest SMC of $38.9 \%$, while RB had $37.5 \%$, and the control section had the lowest SMC of $27.1 \%$. In the first year, the RB section showed higher SMC between August and October, but CB showed higher SMC thereafter (Fig. 2b). It is believed that since carbonized biomass has adsorptive, moisturizing, and permeable properties, the $\mathrm{CB}$ section showed higher SMC than the other sections (Cristner and Walker 1993; Lehmann et al., 2006; Lee et al., 2007; Laird et al., 2010). Rainfall totaled $190.1 \mathrm{~mm}$ during the first year of measurement, with the highest precipitation $(65.0 \mathrm{~mm})$ in November and lowest $(18.0 \mathrm{~mm})$ in October. Total rainfall in the following year was $674.5 \mathrm{~mm}$, with the highest precipitation $(269.7 \mathrm{~mm})$ in July and the lowest $(9.2 \mathrm{~mm})$ in January. In the forest, SMC acts directly and indirectly on root and microbial activities and physiochemical properties of the soil, while also impacting the Rs rate (Davidson et al., 1998; Liu et al., 2002; Kong et al., 2016). However, the present study did not find any correlations between the SMC and Rs rate. It is thought that, while forest soils tend to show a correlation, our experiments in farmland soils did not show significant correlations due to the influence of multiple variables (e.g., physicochemical properties of soil, such as maximum water-holding capacity, as well as rainfall intensity, and temporary increase and decrease in SMC from rainfall) (Davidson et al., 2002).

\section{Decomposition rate}

The highest decomposition rates in the $\mathrm{CB}$ and $\mathrm{RB}$ samples were found 1 month after placement, and subsequently, a high decomposition rate was seen after 4 months; after 4 months, the rate tended to stabilize. Decomposition rate was distinctly higher in the RB, versus the $\mathrm{CB}$, samples. The mean decomposition rate of the RB samples in the first year was $38.4 \%$, which showed a large difference from the mean decomposition rate $(9.2 \%)$ found in the $\mathrm{CB}$ samples. The mean decomposition rate of the RB samples in the following year was $46.2 \%$, which was $7.8 \%$ higher than the first year. Meanwhile, the mean decomposition rates of the $\mathrm{CB}$ samples in the following year were 10.1 and $0.9 \%$ higher than the first year (Fig. 6). Decomposition rate showed an increasing trend, with a temporary decrease during

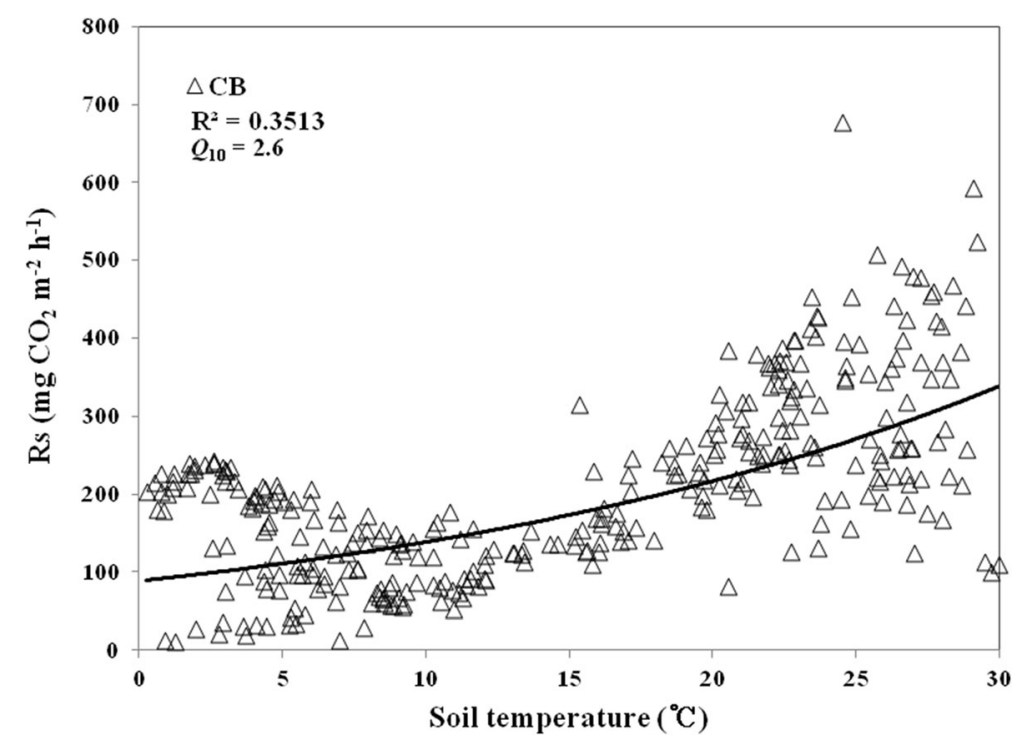

Fig. 3 Relationship between soil respiration rate (Rs) and soil temperature (Ts) at 5-cm depth in the carbonized biomass (CB) section in the first and second year of the experiment 


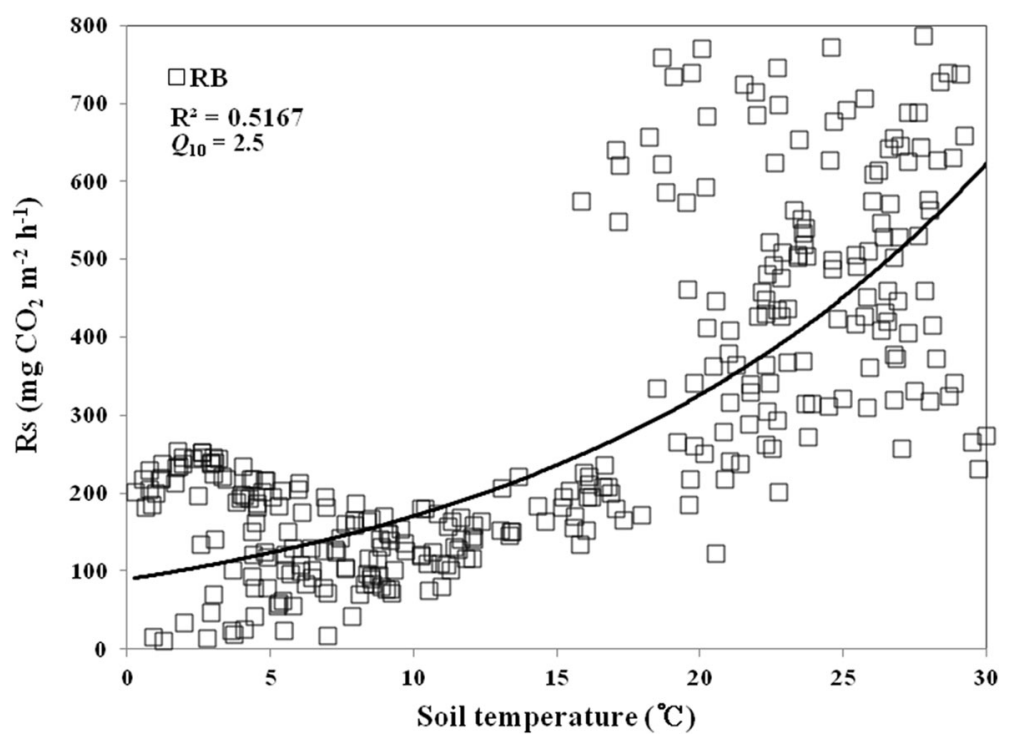

Fig. 4 Relationship between soil respiration rate (Rs) and soil temperature (Ts) at 5-cm depth in the red pepper residue biomass (RB) section in the first and second year of the experiment

winter. This was similar to a previous study by Agren et al. (1991), which reported that when Ts drops below $0{ }^{\circ} \mathrm{C}$, it affects microbial activities; this causes a temporary decrease in the decomposition rate of organic matter, whereas the rate increases rapidly when Ts reaches $10-30{ }^{\circ} \mathrm{C}$.

The RB samples contained substances that could be easily decomposed into organic matter; therefore, robust decomposition occurred early, resulting in a high decomposition rate that corresponded to the aforementioned high Rs rate. The higher decomposition rate in the RB samples was consistent with a previous study that reported residual organic matter in soil can affect the Rs rate by influencing microbial activities (Chapman, 1979). Therefore, it is concluded that high $\mathrm{CO}_{2}$ emission in the RB section was the result of active decomposition of residue organic matter buried in the soil. In contrast, the lower decomposition rate in the $\mathrm{CB}$ samples is believed to be the result of the depletion of most of the carbon content from the carbonization process, and any remaining carbon would be difficult to decompose by

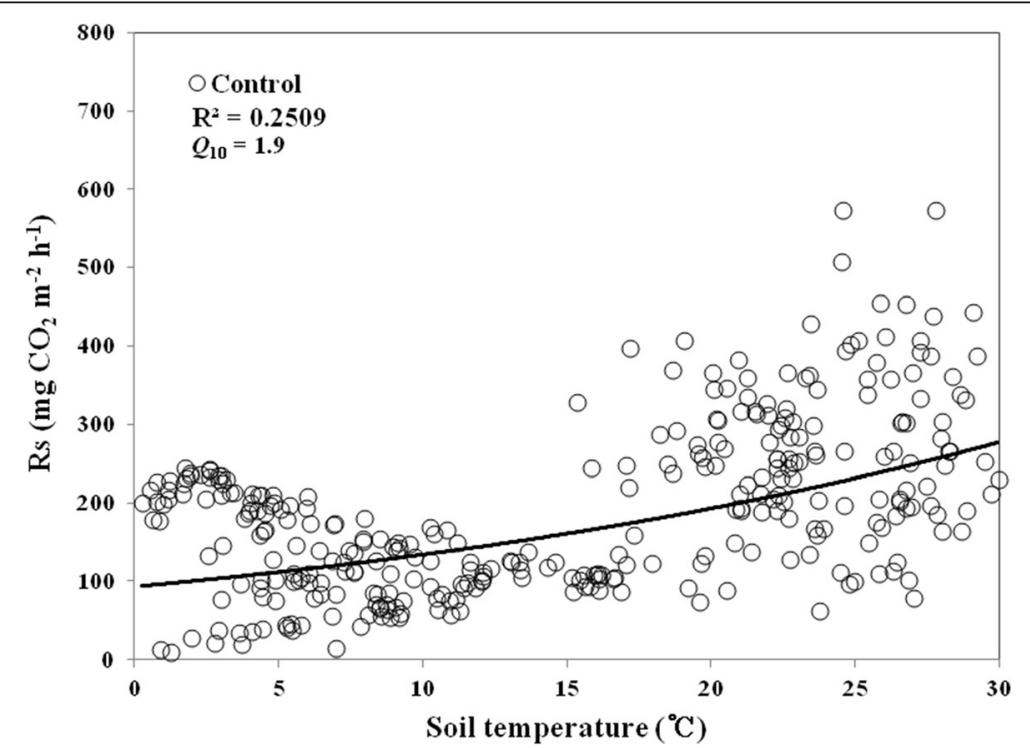

Fig. 5 Relationship between soil respiration rate (Rs) and soil temperature (Ts) at 5-cm depth in the control section in the first and second year of the experiment 


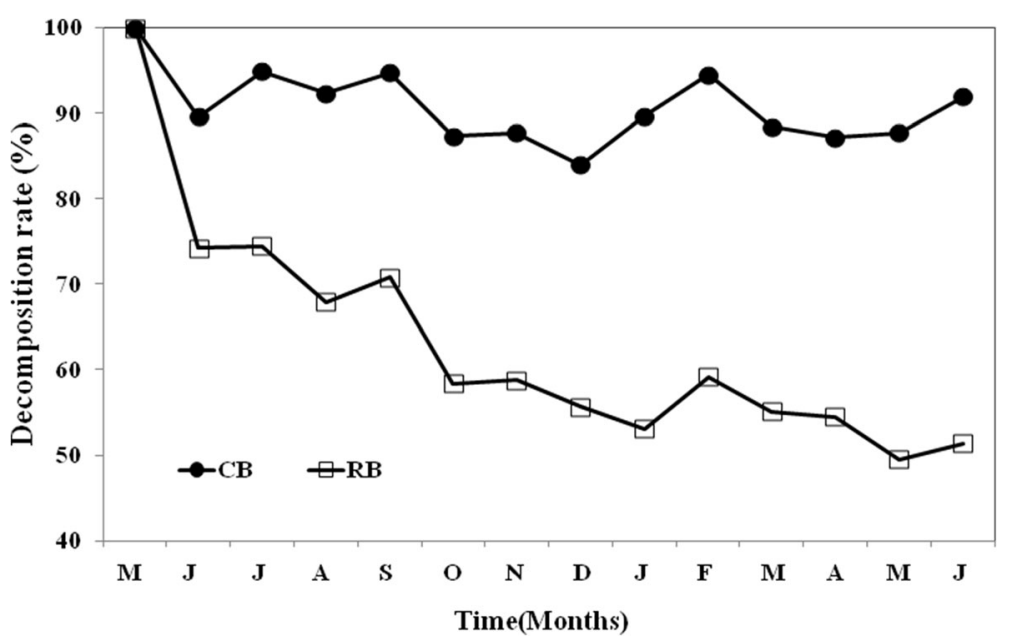

Fig. 6 Decomposition rate of carbonized biomass (CB) and red pepper residue biomass (RB) in the first and second year of the experiment

microbial activities. This is consistent with the $\mathrm{CB}$ section having a lower Rs rate than the $R B$ section. Carbonized biomass is a byproduct of anaerobic thermal decomposition. Moreover, because it is non-degradable organic matter that retains carbon bonding, it does not decompose in soil for a long time. Because it is comprised of approximately $80-90 \%$ carbon, the amount being returned to the atmosphere was low due to a distinctly reduced decomposition rate; thus, $\mathrm{CO}_{2}$ emission was also reduced (Cristner and Walker 1993; Lehmann et al., 2006; Lee et al., 2007; Laird et al., 2010, Liu et al., 2016).

The high decomposition rate of the $\mathrm{RB}$ samples is suspected to be similar to the amount of $\mathrm{CO}_{2}$ emitted during the carbonization process. Organic matter gradually decomposed over time and the decomposition rate slowed as the amount of non-degradable substances increased, as with the carbonized biomass. However, since biomass organic matter cannot be turned into carbonized biomass in the soil, most of the organic matter is expected to undergo decomposition.

\section{Conclusions}

In the present study, residue biomass generated from red pepper farming was carbonized and buried in farmland soil for investigation of carbon accumulation in soil. The study established three sections: control, red pepper residue $(\mathrm{RB})$, and carbonized red pepper residue $(\mathrm{CB})$.

The Rs rate was lower in the $C B$ section than in the $\mathrm{RB}$ section. In the first year, the Rs rates in the $\mathrm{RB}$ and $\mathrm{CB}$ sections were 276.9 and $226.7 \mathrm{mg} \mathrm{CO} \mathrm{CO}^{-2} \mathrm{~h}^{-1}$, respectively, with a difference of $18.1 \%$; the following year, the Rs rate in the $\mathrm{CB}$ section $\left(204.0 \mathrm{mg} \mathrm{CO} \mathrm{m}^{-2} \mathrm{~h}\right.$ ${ }^{-1}$ ) was $38.2 \%$ lower than the $\mathrm{RB}$ section $(330.1 \mathrm{mg} \mathrm{CO}$ $\left.\mathrm{m}^{-2} \mathrm{~h}^{-1}\right)$. Based on these results, it was confirmed that burying carbonized red pepper residue in the soil caused the Rs rate to decrease. Moreover, regression analysis for investigating the correlation between Rs and Ts $(5 \mathrm{~cm})$ showed $R^{2}=0.51,0.35$, and 0.25 for $\mathrm{RB}, \mathrm{CB}$, and control sections, respectively, indicating the highest correlation between Rs and Ts in the RB section.

The mean decomposition rates of the $\mathrm{RB}$ and $\mathrm{CB}$ samples were approximately 41.4 and $9.7 \%$, respectively, showing that the $\mathrm{CB}$ samples had a distinctly lower decomposition rate than the $\mathrm{RB}$ samples. The results indicated that the decomposition and Rs rates were reduced through carbonization of residue biomass organic matter. More research is needed to quantify the amount of carbon released during the carbonization process.

\section{Abbreviations}

CB: Carbonized biomass; RB: Red pepper residue biomass; Rs: Soil respiration; SMC: Soil moisture content; Ta: Air temperature; Ts: Soil temperature at 5-cm depth

\section{Acknowledgements}

Not applicable

Availability for data and materials Not applicable

Funding

This work is based upon research project, "NIE-BR-2017-16," Korea.

\section{Authors' contributions}

All authors conducted a survey together during the study period. J-HL wrote the manuscript. J-SL participated in the design of the study and examined the manuscript. All authors read and approved the final manuscript.

Ethics approval and consent to participate

Not applicable

Consent for publication

Not applicable

Competing interests

The authors declare that they have no competing interests. 


\section{Publisher's Note}

Springer Nature remains neutral with regard to jurisdictional claims in published maps and institutional affiliations.

\section{Author details}

'Division of Ecosystem Services \& Research Planning, National Institute of Ecology, Chungnam 33657, Republic of Korea. ${ }^{2}$ Department of Biological Science, Konkuk University, Seoul 05029, Republic of Korea.

Received: 26 September 2017 Accepted: 22 November 2017

Published online: 06 December 2017

\section{References}

Agren, G. L., McMurtie, R. E., Parton, W. J., Pastor, J., \& Shugart, H. H. (1991). Stateof-the-art of model of production-decomposition linkage in conifer and grassland ecosystems. Ecological Applications, 1, 49-53.

Boone, R. D., Nadelhoffer, K. J., Canary, J. D., \& Kaye, J. P. (1998). Roots exert a strong influence on the temperature sensitivity of soil respiration. Nature, $396,570-572$.

Buchmann, N. (2000). Biotic and abiotic factors controlling soil respiration rates in Picea abies stands. Soil Biology \& Biochemistry, 32, 1625-1635.

Campbell, C. A., Janzen, H. H., Paustian, K., Gregorich, E. G., Sherrod, L., Liang, B. C, \& Zentner, R. P. (2005). Carbon storage in soils of the North American Great Plains. Effect of cropping frequency. Agronim J, 97, 349-363.

Chae, N. Y., Kim, R. H., Suh, S. U., Hwang, T. H., Lee, J. S., Son, Y. H., Lee, D. W., \& Kim, J. (2005). Intercomparison experiment of chamber methods for soil respiration measurement using on phytotron system. Korean Journal of Agricultural and Forest Meteorology, 7(1), 107-114.

Chapman, S. B. (1979). Some interrelationships between soil and root respiration in lowland Calluna heathland in Southern England. Ecology, 67, 1-20.

Cristner, L. G., \& Walker Jr., P. L. (1993). Molecular sieve character of carbons derived from celluosic precusors. Carbon, 31, 1149-1158.

Curtin, D., Wang, H., Selles, F., McConkey, B. G., \& Campbell, C. A. (2000). Tillage effects on carbon fluxes in continuous wheat and fallow-wheat rotations. Soil Science Social American Journal, 64, 2080-2086.

Davidson, E. A., Belk, E., \& Boon, R. D. (1998). Soil water content and temperature as independent or confounded factors controlling soil respiration in a temperature mixed hardwood forest. Global Change Biology, 4, 217-227.

Davidson, E. A., Savage, L., Verchot, V., \& Navaro, R. (2002). Minimizing artifacts and biases in chamber-based measurements of soil respiration. Agricultural and Forest Meteorology, 113, 21-37.

Duxbury, J. M. (1995). The significance of agricultural greenhouse gas emissions from soil of tropical agroecosystems. In R. Lal (Ed.), Soil management and greenhouse effect (pp. 279-291). Boca Raton: Lewis Publ.

Fang, C., \& Moncrieff, J. B. (2001). The dependence of soil $\mathrm{CO}_{2}$ efflux on temperature. Soil Biology \& Biochemistry, 33, 155-165.

Glover, J. D., Reganold, J. P., \& Andrew, P. K. (2000). Systematic method for rating soil quality of conventional, organic and integrated apple orchards in Washington State. Agricultural Ecosystem Environment, 80, 29-45.

Gregorich, E. G., Rochette, P., VandenBygaart, A. J., \& Angers, D. A. (2005). Greenhouse gas contributions of agricultural soils and potential mitigation practices in Eastern Canada. Soil \& Tillage Research, 83, 53-72.

IPCC (Intergovernmental Panel on Climate Change). (2001). Climate change 2001: The scientific basis. Contribution of Working Group 1 to the Third Assessment Report, J.T. Houghton (Eds.), Cambridge University Press, Cambridge, United Kingdom and New York, NY, USA.

Jastrow, J. D., Amonette, E. J., \& Bailey, V. L. (2007). Mechanisms controlling soil carbon turnover and their potential application for enhancing carbon sequestration. Climatic Change, 80, 5-23.

Kapkiyai, J. J., Karanja, N. K., Qureshi, J. N., Smithson, P. C., \& Womer, P. L. (1999). Soil organic matter and nutrient dynamics in a Kenyan nitisol under longterm fertilizer and organic input management. Soil \& Biochemistry, 31(13), 1773-1782.

Koizumi, H., Kontturi, M., Mariko, S., Nakadai, T., Bekku, Y., \& Mela, T. (1999). Soil respiration in three soil types in agricultural ecosystems in Finland. Soil and Plant Science, 49, 65-74.

Kong, H.Y., S.A. Park, K.Y. Shim, T.K. Kim, J.S. Lee, S.U. Suh. (2016). A study on annual carbon emission characteristic changes affected by rainfall. Journal of Climate Change Research, 7(4):397-405.

KOSTAT statistics Korea. Crop production statistics. 2005. http://www.kosis.kr. Accessed 20 June 2017.
KOSTAT statistics Korea. Crop production statistics. 2015. http://www.kosis.kr. Accessed 20 June 2017

Kucera, C. L., \& Kirkham, D. R. (1971). Soil respiration studies in tall grass prairie in Missouri. Ecology, 52, 912-915.

Laird, D., Fleming, P., Wang, B., Horton, R., \& Karlen, D. (2010). Biochar impact on nutrient leaching from a Midwestern agricultural soil. Geoderma, 158(3), 436-442.

Lee, E. H., Lim, J. H., \& Lee, J. S. (2010). A review on soil respiration measurement and its application in Korea. Korean Journal Agric. For. Meteorol, 12, 264-276.

Lee, J.-H., Lee, J.-S., Chun, Y.-M., Chae, N.-Y., \& Lee, J.S. (2013). Discussion of soil respiration for understanding ecosystem carbon cycle in Korea. Korean Journal of Ecology and Environment, 46(2), 309-317.

Lee, K., Yoon, K., Choi, D., Jung, J., Choi, W., \& Lim, S. (2013). Agricultural soil carbon management considering water environment. Journal of Environmental Impact Assessment, 139, 224-231.

Lee, M., Nakane, K., Nakatsubo, T., \& Koizumi, H. (2003). Seasonal changes in the contribution of root respiration to total soil respiration in a cool-temperature deciduous forest. Plant and Soil, 25, 311-318.

Lee, O. K., Jo, T. S., \& Choi, J. W. (2007). Changes in properties and surface FT-IR spectra of wood charcoal at different carbonization temperatures. Mokchae Konghak, 35(4), 21-28.

Lee, S.I., Lee, J.-S., Kim, G.-Y., Choi, E.-J., Suh, S.-U., \& Na, U.-S. (2016). Effect of carbonized biomass derived from pruning soil carbon pools in pear. Korean Journal of Environment Agric, 35(3), 159-165.

Lehmann, J., Gaunt, J., \& Rondon, M. (2006). Bio-char sequestration in terrestrial ecosystems - a review. Mitigation and Adaptation Strategies for Global Change, 11, 403-427.

Liu, X., Wan, B., Su, D., Hui, D., \& Luo, Y. (2002). Response of soil $\mathrm{CO}_{2}$ efflux to water manipulation in a tallgrass prairie ecosystem. Plant and Soil, 240, 213-223.

Liu, X., Zheng, J., Zhang, D., Cheng, K., Zhou, H., Zhang, A., Li, L., Joseph, S., Smith, P., Crowley, D., Kuzyakov, Y., \& Pan, G. (2016). Biochar has no effect on soil respiration across Chinese agricultural soils. Sci of the Total Env, 259-265.

Luo, Z. K., Wang, E. L., \& Sun, O. J. (2010). Can no-tillage stimulate carbon sequestration in agricultural soils? A meta-analysis of paired experiments. Agriculture, Ecosystems and Environment, 139, 224-231.

Nakane, K., Yamamoto, M., \& Tsubota, H. (1983). Estimation of root respiration rate in a mature forest ecosystem. Japan Journal Ecological, 33, 397-408.

NIAST. (1988). Methods of soil chemical analysis. National Institute of Agricultural Science and Technology, RDA, Suwon, Korea.

Pan, Z., Wei, Z., Ma, L., \& Rong, Y. (2015). Effect of various stocking rates on grassland soil respiration during the non-growing season. Acta Ecologica Sinica, 36, 411-416

Post, W. M., \& Kwon, K. C. (2000). Soil carbon sequestration and land-use change: processed and potential. Global Change Biology, 6, 317-328.

Pyo, J., Kim, S., \& Mun, H. (2003). A study on the carbon budget in Pinus koreansis plantation. Korean Journal Ecological, 26, 129-134.

RDA. Fertilizer recommendation for crops. 1999

Suh, S. U., Chun, Y. M., Chae, N. Y., Kim, J., Lim, J. H., Yokozawa, M., Lee, M. S., \& Lee, J. S. (2006). A chamber system with automatic opening and closing for continuously measuring soil respiration based on an open-flow dynamic method. Ecological Research, 21(3), 405-414.

Tian, S., Ning, T., Wang, Y., Liu, Z., Li, G., Li, Z., \& Lal, R. (2016). Crop yield and soil carbon responses to tillage method changes in North China. Soil \& Tillage Research, 163, 207-213.

UNFCCC, (2001). The Marrakech Accords and the Marrakech Declaration, available at http://www.unfccc.int/cop7/documents/accords_draft.pdf.

Verma, S. B., Dobermann, A., Cassman, K. G., Walters, D. T., Knops, J. M., Arkebauer, T. J., Suyker, A. E., Burba, G. G., Amos, B., Yang, H., Ginting, D., Hubbard, K. G., Gitelson, A. A., \& Walter-Shea, E. A. (2005). Annual carbon dioxide exchange in irrigated and rainfed maize-based agroecosystems. Agricultural and Forest Meteorology, 131, 77-96.

Wang, W. Zeng, W., Chen, W. Zeng, H., \& Fang, J. (2013). Soil respiration and organic carbon dynamics with grassland conversions to woodland in temperate China. PLoS One, 8, 1-10.

Waring, R. H., \& Running, S. W. (1998). Forest Ecosystems: Analysis at Multiple. Scales, 2nd ed. Academic Press, USA.

$\mathrm{Xu}, \mathrm{M}$. \& \& Qi, Y. (2001). Soil-surface $\mathrm{CO}_{2}$ efflux and its spatial and temporal variations in a young ponderosa pine plantation in northern California. Global Change Biology, 7, 667-677.

Yoo, G.-Y., Kim, H.-J., Kim, Y.-S., \& Jung, M.-H. (2012). Soil carbon and microbial activity influenced by pasture and rice paddy management. Korean Journal Soil Sci. Fert, 45(3), 435-443. 